\title{
7.2 Melting Musics, Fusing Sounds \\ Stumpf, Hornbostel, and Comparative Musicology in Berlin
}

\author{
Riccardo Martinelli
}

\section{Naturalism and musical otherness}

Observations on the peculiarities that distinguish the music of various populations always raised the interest of philosophers and musicians. Ancient Greeks used to assign ethnic names such as Doric, Phrygian, Lydian, etc., to their different scales, but curiosity as to the variety of the exotic musical systems remarkably increased in the modern age. Geographic discoveries face the Europeans with puzzling forms of musical otherness, and some attention begins to be paid to the repertory of the domestic barbarians living in the countryside of cultivated Europe. ${ }^{I}$ Yet, it is only by the beginning of the twentieth century that a systematic discipline with genuine scientific ambitions eventually begins its process of institutional recognition under the name of comparative musicology. ${ }^{2}$

A major role in this process is played by Carl Stumpf and his pupil Erich Moritz von Hornbostel, who initiated the so-called Berlin School of vergleichende Musikwissenschaft [Fig. 12]. ${ }^{3}$ As they clearly recognized, technological progress has an important part in this development. Until then, the study of exotic music had relied upon the haphazard and amateurish transcriptions into the Western notational system made by missionary fathers or musically educated travelers. The possibility of recording music on Edison phonographic cylinders permanently changed this state of affairs. ${ }^{4}$ Primitive as they may appear today, phonographic recordings allow preservation, promote objectivity and provide a general idea of timbre and other performative characteristics of the recorded items.

Yet, intellectual factors must be also considered in the development of comparative musicology. As I shall argue, Stumpf's attitude toward the phenomena of music perception are among them. With his theory of 'tonal fusion', Stumpf demonstrates an anti-naturalistic and yet scientifically minded attitude, which he consciously opposes to Hermann Helmholtz's physiological explanation of the true foundations of music. In my view, Stumpf's rejection of Helmholtz's natural- 


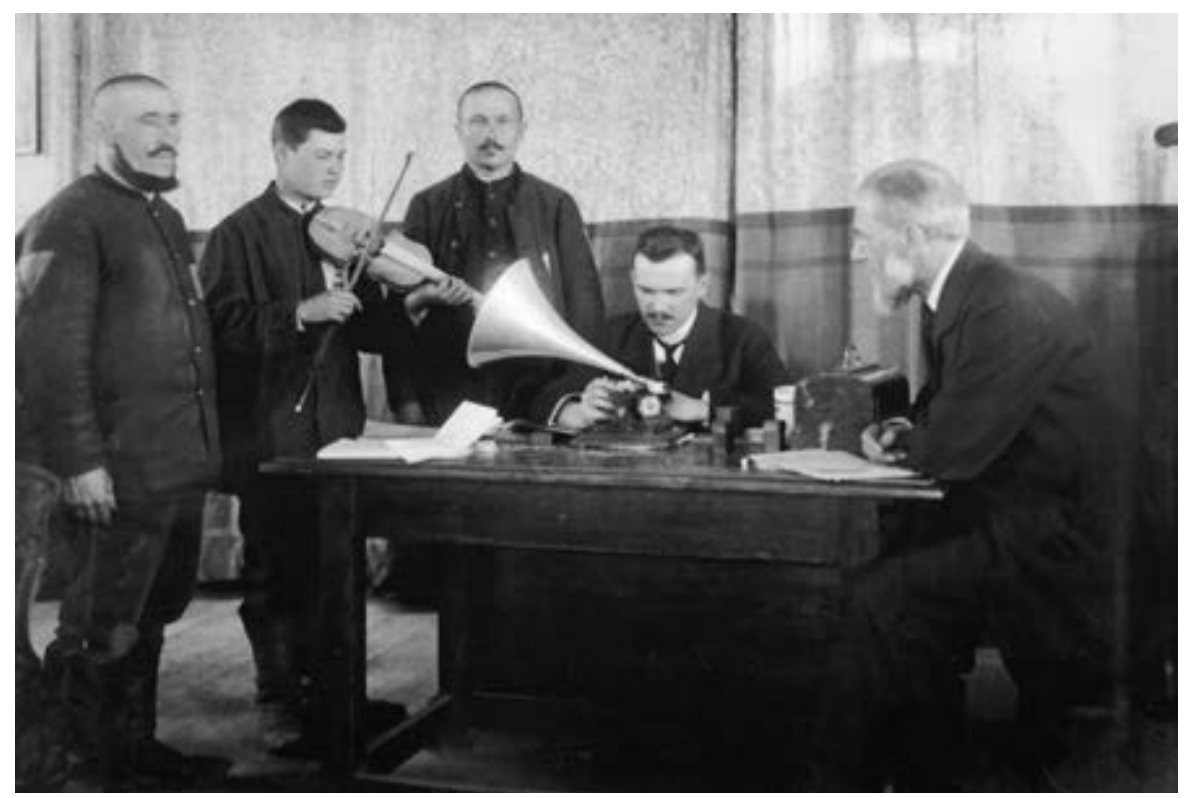

Fig. 12. Georg Schünemann and Carl Stumpf Recording Tatar Singers, 1916, photo, The Sound Archive of Humboldt University, Berlin (HZK Bilddokument ID8249,

Sammlungszugehörigkeit Lautarchiv, Inventar-Nr. Sign. Pn. 1003/5)

ism explains and justifies his interest toward extra-European and folk music as legitimate and autonomous objects of scientific study.

A short definition of what 'naturalism' means in this context is now appropriate. Naturalism is probably the mainstream in the history of philosophy of music, from the Pythagoreans to Zarlino, Rameau, Euler, Helmholtz and many others. Despite obvious differences, these thinkers share the general view that a convincing explanation of music should insist on the nature of sound, its mathematical or physical properties, whose structures are somehow reflected into musical facts by virtue - at least for modern naturalists - of the physiological structure of the ear. Helmholtz himself stresses the continuity between Pythagoras' 'enigma', as he says, and with Rameau, d'Alembert and Tartini, and his own solutions. ${ }^{5}$

Although this definition of naturalism may appear rather loose and generic, it will serve its relatively modest present scope. It should be noted, in fact, that naturalism allows and sometimes suggests an objective criterion for the classification of musical systems. In other terms, a frequent corollary (sometimes explicit, sometimes not) of naturalism is that Western tonal music satisfies the requirements of a 'perfect' musical system much better than any other form of music. This does not necessarily mean that naturalists ignore, dismiss or despise other forms of music. They aren't necessarily more Eurocentric than their adversaries 
or the average of their times. Helmholtz, who has a good knowledge of exotic musical systems, insists that the path toward perfect intonation has still to be accomplished even within Western tonal music. ${ }^{6}$ But naturalists sometimes incline to underestimate the differences among musical systems, perhaps in the ecumenical attempt of including all forms of music within their paradigm. Jean-Philippe Rameau, for instance, is deeply convinced that every people of the world actually uses tonal triads, at least in a melodic disposition, and that the savages sing using our same intervals or, as he says, 'aussi juste que nous.7 In his time, Jean-Jacques Rousseau had been able to distinguish the differences between musical systems with more precision; in Helmholtz's time, it was Stumpf who recognized them most clearly and felt the need for an independent science devoted to that subject.

\section{The Berlin School}

Stumpf's anti-naturalistic philosophical assumptions, then, have had a strong influence upon the origins of comparative musicology in Berlin. This link has been often neglected in literature, and surely not by accident. For opposite reasons, both musicologists and historians of philosophy often pay little attention to these marginal areas. The more so in the case of Stumpf, whose work is still nowadays relatively underestimated. ${ }^{8}$ Let us begin with a brief sketch of his life and work. Born in 1848 , young Carl Stumpf plans to devote himself half-professionally to music until he meets Franz Brentano, whose impressive intellectual figure leads him to philosophy. Stumpf later studies with Hermann Lotze in Göttingen, where he also attends Wilhelm Weber's lessons on physics. In I873 Stumpf begins his academic career: he is appointed professor in Würzburg, then in Prague, Halle, Munich and finally in Berlin, where he resides from I894 until his death in 1936. Erkenntnislehre, his two-volume work published posthumously, demonstrates that Stumpf, who retired in the I920s, remained an active thinker and writer until the last days of his long life. ${ }^{9}$

Although Stumpf follows Brentano's phenomenological (more precisely: descriptive) program in psychology, he also diverges from him in many aspects. Most notably, he has a deeper commitment in experimentation and in empirical science. Stumpf devotes a considerable amount of his time in the investigation of sound perception. He publishes his results in 1883 and in 1890 in two volumes entitled Tonpsychologie (Psychology of Sound)..$^{10}$ In Berlin, as a teacher and head of the Institute for Psychology, Stumpf has an important part in the birth of Gestalt psychology. Actually, the theories of Wertheimer, Koffka, and Köhler diverge from many of Stumpf's ideas; yet, his attitude toward phenomenological observation and experimental activity undoubtedly influences the Gestaltists' 
scientific program. ${ }^{\text {II }}$ Stumpf didn't aim at establishing an orthodoxy. Perhaps for this reason, the Berlin group (also including Kurt Lewin and, for a while, Robert Musil) respected him deeply, as manifested by the celebratory issue of the journal Psychologische Forschung on his 75 th anniversary. ${ }^{12} \mathrm{Had}$ not the Nazis dispersed the human and scientific heritage of the Berlin School, Stumpf's pioneering work in many fields of research would have been more widely remembered and recognized.

As far as ethnomusicology (as one would currently say) is concerned, Stumpf begins his career in Halle in I885 with a study on the songs of a North American Indian tribe. ${ }^{13}$ At that time Stumpf doesn't have a phonograph yet: his first recording occurs in Berlin, in $1900 .{ }^{14}$ In the same year, Stumpf sets up the Phonographic Archive (Phonogramm-Archiv), a collection of Edison cylinders whose direction is taken up by Hornbostel from 1905 to 1933. A Phonographic Archive aiming at recording both musical and spoken linguistic items had already been established in Vienna in 1899. Yet the Berlin collection, focused on music, became the largest and most important in the world from this point of view. Stumpf and Hornbostel prompted their Berlin colleagues involved in expeditions to record music and songs of the visited countries. During the First World War, Stumpf could record songs of war prisoners from all over the world; a program of exchanges with Franz Boas also enriched the archive with many more cylinders and later also gramophone recordings. ${ }^{15}$

\section{Mixed sensations: Stumpf on tonal fusion}

In which sense, then, did Stumpf's philosophical stance influence and foster his interest toward exotic and folk music? Let us first consider Stumpf's key concept of 'tonal fusion' (Tonverschmelzung) as illustrated in the second volume of his Tonpsychologie. According to Stumpf, the basis of consonance lies in a tendency of the perceived tones to 'fuse together'. The more two given tones do so, the more they are perceived as consonant. Musical consonance is then the surface of a deeper psychological phenomenon, i.e., fusion. The definition given by Stumpf is the following:

Fusion is that relationship of two sense-perceived elements in which they form not a mere sum but rather a whole. The result of this relationship is that with greater levels of fusion the overall impression, under otherwise identical circumstances, approaches closer and closer to the one of a single perception, and becomes increasingly difficult to break down. ${ }^{16}$ 
As Wolfgang Köhler later recognized, Stumpf's speaking of the 'whole' in this passage represents a step forward in the direction of Gestalt theory. ${ }^{17}$ More significantly, however, Stumpf's ideas must be read in the light of ancient philosophical theories and their nineteenth-century developments. In the treatise concerning sensation in the Parva naturalia, Aristotle notes that mixed sensations, if compared with pure ones, are less easily perceived. This happens, for instance, in the case of wine or honey, but also for colors and sounds. ${ }^{18}$ In Stumpf's times, these ideas of Aristotle's had been experimentally confirmed by the physiologist Ernst Heinrich Weber, to whom Stumpf had been introduced by his brother Wilhelm Weber, who was his teacher in physics. ${ }^{19}$ In a famous series of experiences concerning the sense of touch, which later also inspired Gustav Theodor Fechner's psychophysics, Ernst H. Weber had demonstrated that weighing two given bodies successively, with the same hand, improves our ability to discern the differences. By contrast, the simultaneous evaluation with both hands easily misleads us. In this case, Weber argues, the two sensations tend to 'mix' and then to confound the subject. ${ }^{20}$

Stumpf, who explicitly quotes Ernst $\mathrm{H}$. Weber, ${ }^{21}$ does little more than applying this well-tested model to tonal perception. The two simultaneous sensations of tone (Tonempfundungen) mix and thus mislead the subject, who believes he is hearing one single tone. Thus, this error is the key to the whole phenomenon. According to Stumpf, systematic errors are of utmost importance in psychology, since they show how the perceptual system actually works. ${ }^{22}$ Stumpf experimentally determines five degrees of tonal fusion: the octave, the fifth, the fourth, the thirds and sixths (major and minor) and all the remaining intervals. ${ }^{23}$ However, we don't need to provide further details here. Despite being harshly criticized, ${ }^{24}$ Stumpf's idea of tonal fusion seems to still be attractive to psychologists and musicologists. ${ }^{25}$

It is remarkable that Stumpf consciously conceived tonal fusion as an alternative to the prevailing naturalistic approach of Hermann Helmholtz. In his Lebre von den Tonempfindungen (1863), Helmholtz offers an innovative and convincing explanation of musical perception. He shows that a complete set of fibers of different lengths that are located in the inner ear correspond to each audio frequency. ${ }^{26}$ Helmholtz draws on the classical comparison between the inner ear apparatus and a piano, whose strings are set free to resonate. Consonance thus originates from the physical and mathematical affinity of sounds. Many scholars, including, most notably, Ernst Mach, found this explanation partially inadequate: Helmholtz's liberality in admitting single resonating fibers and the correspondent specific nervous 'energies' seemed excessive. ${ }^{27}$ However, whereas Mach aims at correcting and ameliorating Helmholtz's theory, with tonal fusion Stumpf offers a radical alternative to it, thus diverging from the mainstream of his time. ${ }^{28}$ 
A remarkable consequence of Stumpf's researches is that music becomes possible through a sort of illusion, a failure of the perceptive system. Far from faithfully grasping the acoustic world by virtue of the analysis of sounds performed in the inner ear, music originates for Stumpf from a perpetual filter, which is permanently imposed upon human hearing. Tonal fusion is the scientific measure of this inertial force. As previously noted, Weber had shown the way human sensibility works: on the basis of his experimental work, he could ascertain the appropriate function (curve) for each sensory field. Similarly, Stumpf's experiments on fusion show the way human sensibility works whenever a multiplicity (Mebrheit) of simultaneous tones is involved. ${ }^{29}$ These aspects are capital to Stumpf's phenomenological approach, and help distinguishing it more clearly from naturalism..$^{30}$ Whereas in his opinion tonal fusion introduces a gap between sound as natural phenomenon and the perception of music, naturalists like Helmholtz tend to see a smooth transition from sound perception to the appreciation of music with its aesthetic content, suggesting that our ears provide us with a faithful picture of what is going on in the acoustic world. For Stumpf, by contrast, music becomes possible just because we (partly) fail to perceive the physical reality of acoustics as it is. As we all know, other forms of art, including cinema, are likewise based upon an illusion, a deception of the visual system which is unable to distinguish single frames in quick succession - as the Gestalt theorists knew very well. But music, with its sometimes almost inebriating effect, is perhaps more reminiscent of the Aristotelian example of a blended wine, whose mixing flavors would be irremediably lost for a merely analytical sense of taste.

\section{Stumpf as ethnomusicologist}

We have now a better overall view, enabling us to appreciate Stumpf's interest in exotic music and to interpret it correctly. As early as 1883 , in the preface to the first volume of Tonpsychologie, ${ }^{31}$ Stumpf includes the comparison of peoples and times' among the auxiliary methods of general psychology, and observes that their integration succeeds particularly in psychology of music. Two years later, in I885, in the above-mentioned study on North American Indians, Stumpf underlines the value of comparative research not only for the purposes of historical investigation, but also for those of psychology in general and for aesthetics. ${ }^{32}$ Conversely, Stumpf stresses the importance of music for anthropology: a common patrimony of music systems or songs can bear witness of the common origin of distant human groups. In September 1900, in Berlin, Stumpf studies and records a royal orchestra coming from Siam (Thailand). Stumpf provides a detailed and accurate report on musical instruments, their tuning, the performed music and 
reports some experiences on some of the most gifted musicians' musical ear. This allows him to confirm Alexander Ellis's hypothesis that the musical scale adopted by Siamese musicians consists of seven equal intervals within an octave. Stumpf ends this exemplary essay with some methodological remarks. The utility of compared musicology for 'general ethnology and the history of humankind' is surely out of question; yet, Stumpf insists, it also represents a fruitful task for the psychologist or the aesthetics scholar who is ready to abandon the 'parlor of scholars' (Gelebrtenstube) and the method of self-observation, and wishes to 'widen his horizon by means of an objective study of human thinking and feeling [Denkens und Füblens] in other times and spaces., ${ }^{33}$ The more so, Stumpf concludes, since these forms of music presently die off as a result of the Europeans' cultural pressure: it is time to collect and to preserve them. His foundation of the Archive in the same year serves precisely to this scientific scope.

In I9Io, together with Hornbostel, Stumpf exposes his ideas and results to his colleagues at the Fourth Congress on Experimental Psychology of Innsbruck. He contrasts the old Herbartian introspective method with the open-mindedness of Theodor Waitz, a philosopher and psychologist who turned to ethnological research and wrote the monumental Anthropologie der Naturvölker. ${ }^{34}$ Psychology should open its doors to ethnological research and reconnect them with experimentation: both disciplines will profit from this process. The ideal path from tonal fusion to ethnomusicology is justified within the frame of a clearly stated and frequently reaffirmed scientific program. ${ }^{35}$

\section{Hornbostel: Music and culture}

Stumpf's younger friend and follower as director of the Archive, Erich Hornbostel, echoes these general ideas. Given his further achievements, he actually deserves Jaap Kunst's definition of 'facile princeps among all those who have made of ethnomusicology the chosen subject of their study'. ${ }^{36}$ Whereas Stumpf is permanently engaged in many different undertakings and academic commitments, Hornbostel intensively and primarily attends to comparative musicology, partly in cooperation with Otto Abraham and Georg Schünemann. Together with Curt Sachs, he devoted much effort to the study, the collection and the classification of musical instruments. ${ }^{37}$ With his friend Max Wertheimer, who himself studies the music of the primitive Weddas of Ceylon, Hornbostel especially investigates the psychological problem of perceiving the sound direction..$^{38}$

In an essay from i9ıo, Hornbostel underlines the close relation of musicology, ethnology and psychology. ${ }^{39}$ In analyzing the causes of the widespread intellectual resistance against comparative methods, Hornbostel keenly observes that 
many researchers are still convinced that music is everywhere a 'natural universal language' which deserves much more attention than any of its 'dialects'. Moreover, many are convinced that the so-called 'savages' are not able to bring out anything but 'noise and ugly uproar', which one should reasonably compare to animal cries and not to our music. Hornbostel is then much more explicit than Stumpf in his criticism of naturalism and of its Eurocentric implications.

Also in his case, a robust set of theoretic assumptions forms the background of his interest in comparative musicology. Rather than adopting Stumpf's tonal fusion, Hornbostel eventually develops an original theory of auditory perception of his own. His theses and results have been often criticized by psychologists and musicologists. In any case, Hornbostel is much closer than Stumpf to the Gestaltists' ideas. He pays special attention to two themes: the unity of senses and the holistic aspects of music perception:

What is essential in the sensuous-perceptible is not that which separates the senses from one another, but that which unites them: unites them among themselves, unites them with the entire (even with the non-sensuous) experience in ourselves, and with all the external world that there is to be experienced. ${ }^{40}$

Even more decidedly than Stumpf, Hornbostel thus rejects naturalism and conceives of music as cultural phenomenon. He also provides a gestalt-oriented interpretation of cultural phenomena. In his view, sensible and intellectual gestalts form a net, whose knots are joined together in different manners or 'styles' within different cultures. The musicologist aiming at reconstructing and interpreting styles should consider each element - a melodic or harmonic construct, a rhythmic figure, and so on - as a part in this net of interwoven 'wholes'. Some elements come from the composer's personality, some other from the historical and cultural context he belongs to. Surely not by chance, in this 1930 essay Hornbostel adds some conclusions concerning melting cultures and races: '[T] he crossing of races originates new races; the fusing of cultures (Kulturverschmelzung) leads to new cultures. In both cases, new styles arise. This generates something totally new, not a "hybrid"'.4

Three years later, identified by the Nazis as a 'half-Jew' (Halbjude), Hornbostel was relieved of his post and had to leave Germany, sharing the destiny of many other members of the Berlin School. He first moved to Switzerland and to the United States, and eventually reached Cambridge where he died two years later, at the age of fifty-seven. Needless to say, Hornbostel's interests and views were radically opposed to the plan to restore the supremacy of a purely German art over degenerate music. The Archive was transferred and went through difficult 
times. After the postwar recovery of its material legacy of wax cylinders, it is time to reconsider the virtuous link of philosophical ideas and scientific practice which gave rise to that enterprise.

\section{Notes}

I See Philip V. Bohlman, The Study of Folk Music in the Modern World (Bloomington: Indiana University Press, I988).

2 On this history and its many problems, including the definition of the discipline as comparative musicology or ethnomusicology, see Bruno Nettl, Music in Primitive Culture (Cambridge, MA: Harvard University Press, I956); Idem, The Study of Ethnomusicology: Twenty-Nine Issues and Concepts (Urbana: University of Illinois Press, I983), Idem, Nettl's Elephant: On the History of Ethnomusicology (Urbana: University of Illinois Press, 20I 2); Alan Merriam, The Anthropology of Music (Evanston, ILL: Northwestern University Press, 1956); Bruno Nettl and Philip V. Bohlham (eds.), Comparative Musicology and Anthropology of Music: Essays on the History of Ethnomusicology (Chicago: University of Chicago Press, I99I).

3 Dieter Christensen, 'Erich M. von Hornbostel, Carl Stumpf, and the Institutionalization of Comparative Musicology', in Arthur Simon (ed.), Das Berliner Phonogramm-Archiv 1900-2000 - Sammlungen der traditionellen Musik der Welt/The Berlin Phonogramm-Archiv 1900-2000: Collections of Traditional Music of the World (Berlin: Verlag für Wissenschaft und Bildung, 2000), I4I-I50.

4 Erika Brady, A Spiral Way: How the Phonograph Changed Ethnography (Jackson: University Press of Mississippi), I999, where Stumpf is yet never quoted, and Hornbostel only once.

5 Hermann von Helmholtz, Die Lebre von den Tonempfindungen als physiologische Grundlage für die Theorie der Musik, trans. Alexander J. Ellis, On the Sensations of Tone as a Physiological Basis for the Theory of Music (London, New York: Longmans, Green, and Co., I 885; repr. New York: Dover, I954), 229.

6 Helmholtz, On the Sensations of Tone, 514, 522.

7 Jean-Philippe Rameau, Code de Musique pratique, ou, Méthodes pour apprendre la musique [...]. Avec des nouvelles réflexions sur le principe sonore (Paris: Imprimerie Royale, 1760), 216.

8 However, Stumpf's work is getting more and more attention among scholars. See the translation of his Die Anfänge der Musik (I9I I): Carl Stumpf, The Origins of Music, ed. by David Trippett (Oxford: Oxford University Press, 2012), in a volume also including Stumpf's Selbstdarstellung (I924): 'Carl Stumpf: A Self-Portrait', I 89-252) and two introductory essays by Helga de la Motte-Haber ('Carl Stumpf: Impulses toward a Cognitive Theory of Musical Evolution', 3-I6) and David Trippet ('Carl Stumpf: A Reclutant Revolutionary', I 7-29). See also Nadia Moro, Estetica trascendentale in musica. La psicologia del suono di J.F. Herbart e C. Stumpf (Milano: Mimesis, 20I2). Historians of psychology have also begun to recognize Stumpf's pioneering role. See H. Sprung, Carl Stumpf. Eine Biographie. Von der Philosophie zur experimentellen Psychologie (Munich-Vienna: Profil, 2006).

9 Carl Stumpf, Erkenntnislehre, ed. Felix Stumpf, 2 vols. (Leipzigः Barth, I939-I940).

Io Carl Stumpf, Tonpsychologie, 2 vols. (Lepizig: Hirzel, I 883-I890, repr. Amsterdam: Bonset I965). 
I I See Mitchell G. Ash, Gestalt Psychology in German Culture, 1890-1967: Holism and the Quest for Objectivity (Cambridge: Cambridge University Press, I995), 28-4I and passim.

Festschrift Carl Stumpf zum 75. Geburtstag in Dankbarkeit und Verehrung gewidmet, special issue of Psychologische Forschung 4 (1923).

I 3 Carl Stumpf, 'Lieder der Bellakula-Indianer', Vierteljahrsschrift für Musikwissenschaft 2 (I 886), 405-426. See Martin Müller, 'Carl Stumpf auf dem Wege zur vergleichenden Musikpsychologie', in Margret Kaiser El-Safti and Matthias Ballod (eds.), Musik und Sprache. Zur Phänomenologie von Carl Stumpf (Würzburg: Königshausen \& Neumann, 2003), 2 II-223.

I4 Carl Stumpf,'Tonsystemen und Musik der Siamesen', Beiträge zur Akustik und Musikwissenschaft 3 (I90I), 69-I38.

I5 Simon (ed.), Das Berliner Phonogramm-Archiv, passim. The book contains documents and informations concerning the history of the Archive from its foundation to recent times.

I6 Stumpf, Tonpsychologie, vol. 2, I28.

I7 Wolfgang Köhler, Die physischen Gestalten in Ruhe und im stationären Zustand. Eine naturphilosophische Untersuchung (Braunschweig: Vieweg \& Sohn, I920), 34.

I8 Aristotle, Sens., vii, 447a I7-I 8, in Parva naturalia, ed. David Ross (Oxford: Oxford at the Clarendon Press, I995).

I9 Carl Stumpf, Selbstdarstellung, trans. Thomas Hodge and Susanne Langer, in Carl Murchison (ed.), History of Psychology in Autobiography (Worcester, MA: Clark University Press, I930), vol. I, 389-44I.

20 Ernst Heinrich Weber, Die Lehre vom Tastsinne und Gemeingefüble, auf Versuche gegründet (Braunschweig: Vieweg, I 850), 85-86.

2 I Stumpf, Tonpsychologie, vol. 2, 6I.

22 Ibid., vol. I, vii.

23 Ibid., vol. 2, I35.

24 Christian Allesch, 'Zur Rezeption von Carl Stumpfs Tonpsychologie', in Kaiser-El-Safti and Ballod (eds.), Musik und Sprache. Zur Phänomenologie von Karl Stumpf, 225-236.

25 See, e.g., David Huron,'Tonal Consonance versus Tonal Fusion in Polyphonic Sonorities', Music Perception 9 (I99I), I 35.

26 Helmholtz, On the Sensations of Tone, passim.

27 Ernst Mach, Die Analyse der Empfindungen und das Verbältnis des Physischen zum Psychischen, trans. C.M. Williams, The Analysis of Sensations and the Relation of the Physical to the Psychical (New York: Dover, 1959), 276.

28 See also Riccardo Martinelli, 'Brentano and Stumpf on Tonal Fusion', in Denis Fisette and Guillaume Fréchette (eds.), Themes from Brentano (Amsterdam: Rodopi, forthcoming 2013).

29 Notwithstanding this attitude, Stumpf does not aim at any 'psychophysics' of sounds: his goal is to measure 'sense-judgments' (Sinnesurteile), not sensations. In this sense, his Tonpsychologie is defined as a 'doctrine of the measurement of judgments' (messende Urteilslehre). Stumpf, Tonpsychologie, vol. I, 54. See Alexandra Hui, The Psychophysical Ear: Musical Experiments, Experimental Sounds, 1840-1910 (Cambridge, MA: MIT Press, 20I3); unfortunately, haven't yet been able to consult this book.

30 On Stumpf's phenomenology and its divergence from Husserl's, see Robin R. Rollinger, 'Stumpf on Phenomena and Phenomenology', Brentano Studien 9 (200I), I49-I66.

3 I Stumpf, Tonpsychologie, vol. I, vi.

32 Stumpf,'Lieder der Bellakula-Indianer', 89.

33 Stumpf,'Tonsystemen und Musik der Siamesen', I67. 
34 Carl Stumpf and Erich Moritz von Hornbostel, 'Über die Bedeutung ethnologischer Untersuchungen für die Psychologie und Ästhetik der Tonkunst', in Friedrich Schumann (ed.), Bericht über den IV Kongress für experimentelle Psychologie (Leipzig: Barth, I9II), 256-259. See Theodor Waitz, Anthropologie der Naturvölker, vol. I, Über die Einheit des Menschengeschlechtes und den Naturzustand des Menschen (Leipzig: Fleischer, I859).

35 A strong connection of comparative musicology with psychology clearly emerges. 'Early musical ethnology does not begin as musicology': Sebastian Klotz, 'Hornbostels Nadelkurven', in Sebastian Klotz (ed.), Vom tönenden Wirbel menschlichen Tuns. Erich M. von Hornbostel als Gestaltpsychologe, Archivar und Musikwissenschatfler (Milow: SchibriVerlag, I998), I93.

36 Jaap Kunst, Ethnomusicology: A Study of Its Nature, Its Problems, Methods and Representative Personalities (The Hague: Nijhoff, I974), I 8.

37 Erich von Hornbostel and Curt Sachs, 'Systematik der Musikinstrumente. Ein Versuch', Zeitschrift für Ethnologie 46 (I9I4), 553-590.

38 Erich von Hornbostel and Max Wertheimer, 'Über die Wahrnehmung der Schallrichtung', Sitzungsberichte der Preussischen Akademie der Wissenschaften 20 (I920), 388-396. For a bibliography of Hornbostel's writings, see Erich Moritz von Hornbostel, Tonart und Ethos: Aufsätze zur Musikethnologie und Musikpsychologie (Lepizig: Reclam, I986), 369377 .

39 Erich von Hornbostel, 'Über vergleichende akustische und musikpsychologische Untersuchungen', Zeitschrift für angewandte Psychologie und psychologische Sammelforschung 3 (I910), 465 .

40 Erich von Hornbostel, 'Die Einheit der Sinne', trans. Elizabeth Koffka and Warren Vinton,'The Unity of the Senses', Psyche 7 (I927), 87.

4I Erich von Hornbostel, 'Gestaltpsychologisches zur Stilkritik', in Studien zur Musikgeschichte. Festschrift für Guido Adler zum 75. Geburtstag (Vienna: Universal, I93), I 4. 